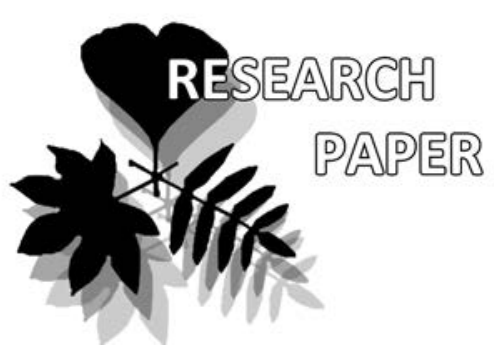

\title{
Pericarp structure in some species in the tribe Sileneae DC. (Caryophyllaceae, Viscaria group)
}

\author{
Tatyana I. Kravtsova ${ }^{1 *} \&$ Yana V. Bolotova ${ }^{2}$
}

Tatyana I. Kravtsova ${ }^{1 *}$

e-mail: TKravtsova@binran.ru

Yana V. Bolotova ${ }^{2}$

e-mail: yabolotova@mail.ru

${ }^{1}$ Komarov Botanical Institute RAS, Saint Petersburg, Russia

${ }^{2}$ Amur Branch of the Botanical GardenInstitute FEB RAS, Blagoveshchensk, Russia

* corresponding author

Manuscript received: 11.10.2018

Review completed: 10.10.2019

Accepted for publication: 29.10.2019

Published online: 02.11.2019

\begin{abstract}
A B S T R A C T
The pericarp structure was studied in the representatives of genera Atocion, Minjaevia, and Viscaria, forming a separate Viscaria clade on the phylogenetic tree of the tribe Sileneae, and in Ixoca, previously a member of this group. It was found that, despite of differences in the capsule morphology and dehiscence in $A$. armeria and $M$. rupestris on the one hand, and $V$. vulgaris on the other, there are many similar features in their pericarp anatomy and micromorphology that supports their close relationships. The highest similarity in the pericarp structure, as well as in the capsule morphology, is between $A$. armeria and $M$. rupestris. Pericarp structure in $V$. vulgaris is less derived compared to them and differs by the absence of silicified palisade layer in the exocarp and indistinct differentiation of pericarp sclerenchyma into different (morphologically and in orientation) cell layers. Pericarp anatomy confirms the separation of genus Ixoca from the Viscaria group.

K e y w o r d s : Caryophyllaceae, Sileneae, Atocion, Ixoca, Minjaevia, Viscaria, fruit, molecular phylogeny, pericarp micromorphology and anatomy, taxonomy
\end{abstract}

\section{P E 3 Ю M E}

Кравцова Т.И., Болотова Я.В. Строение перикарпия у некоторых видов трибы Sileneae DC. (Caryophyllaceae, Viscaria group). Строение перикарпия изучено у представителей родов Atocion, Minjaevia и Viscaria, составляющих на молекулярно-филогенетическом дереве трибы Sileneae клалу Viscaria, а также у Iхоса, ранее входившего в эту кладу. Выяснено, что, несмотря на различия в морфологии и способе вскрывания коробочек у $A$. armeria и $M$. rupestris с одной стороны, и $V$. vulgaris с Аругой, в анатомическом строении и микроморфологии их перикарпия имеется много общих черт, что подтвержАает близкое родство этих таксонов. Наибольшее сходство в строении перикарпия, как и в морфологии коробочек, обнаружено межАу A. armeria и M. rupestris. Менее продвинутая по сравнению с ними структура перикарпия у $V$. vulgaris отличается отсутствием палисадного окремневшего экзокарпия и неотчетливой Аифференциацией склеренхимы на слои, размичающиеся по морфологии и ориентации клеток. Анатомия перикарпия подтвержАает обособленность рода Iхоса от родов группы Viscaria.

Ключевые слова: Caryophyllaceae, Sileneae, Atocion, Ixoca, Minjaevia, Viscaria, микроморфология и анатомия перикарпия, молекулярная филогения, плоА, таксономия
The systematics of the tribe Sileneae (Caryophyllaceae) is currently insufficiently developed; the taxonomic structure and the phylogenetic relationships of the genus Silene L., the largest in the Caryophyllaceae, numbering about 700 species, are debatable issues. It is considered sometimes to be very wide and includes almost all of other genera of the tribe, except Agrostemma L. (Greuter 1995), then divides into large numbers of small genera, the largest number in Tzvelev (2001) classification. The taxonomic revisions of the tribe also vary significantly in the opinion of authors from our country (Tzvelev 2001, Lazkov 2003, 2006). Molecular phylogenetic studies of the Sileneae with different molecular markers of nuclear and chloroplast origin (Oxelman \& Lidén 1995, Oxelman et al. 1997), allowed elucidation of genera relationships in the tribe. These investigations revealed that separate clades on the molecular phylogenetic trees are as follows: basal clades Agrostemma, Eudianthe, Petrocoptis, the
Viscaria group, the Lychnis group, and the terminal one, the largest Silene group, including two subclades. The Viscaria group initially included four morphologically distinct small genera: Atocion Adans., Ixoca Raf. (=Heliosperma (Rchb.) Rchb.), Minjaevia Tzvel. and Viscaria Bernh., the close relationships of which is very doubtful in the opinion of Tzvelev (2001). The close relationships between Atocion and Viscaria is one of the unexpected results obtained by Oxelman \& Lidén (1995), which was confirmed by all subsequent molecular studies (Fraiman, Heidari \& Oxelman 2009). In the previous classifications of the tribe, on the base of traditional methods, the Atocion was related to Silene s.str., and Viscaria to Lychnis (for example, Chowdhuri 1957). The contradictions with the traditional systematics of the tribe Sileneae are associated with the possible reticular character of their evolution (Erixon \& Oxelman 2008, Fraiman, Heidari \& Oxelman 2009, Mikhailova 2016b). 
According to recent data (Fraiman \& Oxelman 2007, Fraiman, Eggens \& Oxelman 2009), the position of Ixoca as a sister group, in relation to Viscaria vulgaris, is erroneous; its real position within Sileneae remains unclear. A study of this genus with the involvement of low-copy nuclear genes indicates its hybrid origin. At least two lineages have been involved in the origin of Ixoca: an ancestor of Viscaria and Atocion and the other of Eudianthe Rchb. and/or Petrocoptis A. Braun ex Endl. (Fraiman, Eggens \& Oxelman 2009). Recent results (Mikhailova 2016a, b) have shown that genus Ixoca forms a separate basal clade on the molecular phylogenetic tree.

The data of molecular phylogenetic analysis resulted in the revision of the tribe Sileneae classification, in which 8 genera were recognized (Oxelman et al. 2001). Monotypic genus Minjaevia (Minjaevia rupestris (L.) Tzvel.) was included in Atocion, as Atocion rupestre (L.) Oxelman (Oxelman et al. 2001, Fraiman, Heidari \& Oxelman 2009, Fraiman et al. 2013).

The close relationships between Atocion and Viscaria can be considered as an example of glaring contradictions between morphology and molecular phylogeny, which are not uncommon in modern botany. There are significant variations within the Viscaria group in several carpological characters used in Sileneae taxonomy to distinguish genera: carpel and capsule teeth number; septa presence or absence; septicidal or loculicidal dehiscence. Capsules of $A$. armeria and $M$. rupestris have some characteristic features of Silene s.str.: three styles, a loculicidal-septicidal capsule with incomplete septa, dehiscent via 6 teeth. These genera are included sometimes into Silene s.l., in the sections Compactae (Boiss.) Schischk. and Nanosilene Otth (or Rupifraga Otth), respectively (Schishkin 1936, Chowdhuri 1957).

Viscaria and Ixoca capsules have another structure. In $V$ vulgaris, there are five styles, capsules are five-locular with incomplete septa, with unique loculicidal dehiscence via five teeth. In Ixoca species, there are three styles, capsules are one-locular, without septa, loculicidal-septicidal, dehiscent via six teeth.

The anatomical structure of fruits in the species, constituting the Viscaria group, as well as in the whole tribe Sileneae, is insufficiently studied. The pericarp structure was investigated in capsule teeth region in Viscaria vulgaris, Ixoca carpatica (=Heliosperma quadrifidum), and several Lychnis, Melandrium and Silene species (Weberbauer 1898, Guttenberg 1971). Exocarp sclereids in teeth region were found to be specialized cells - large, thick-walled, with strongly thickened U-shaped secondary wall, they take part in capsule dehiscence along septa and/or mid ribs. Their cell walls have transverse (in relation to capsule longitudinal axis) strands-like thickenings. Various thicknesses of outer and inner sclereid walls in the exo- and mesocarp, and the presence of unlignified inner layers contribute to the curvature of the pericarp in the teeth at drying. Between Viscaria, Silene, Lychnis, Melandrium on the one hand, and Heliosperma, Petrocoptis, certain Alsineae on the other, the differences are detected in teeth structure - in the number of mechanically active layers of sclereids, the form of sclereids, the form of their wall thickenings.

In some of the species, different anatomical types of the dehiscence were previously identified (Devyatov 1991): in Ixoca arcana (Heliosperma alpestre) at the site of cracking cells of the exocarp are smaller (lower) than neighboring cells, in Viscaria vulgaris, the cells of subepidermal layer are smaller. This character, however, varies in the second species. In a number of works, there are data on exocarp micromorphology for several species (Melikian \& Devyatov 2000, Kravtsova \& Romanova 2015, Kravtsova 2017): it was found to be colliculate in Atocion, Minjaevia, Viscaria, and a different type in Ixoca.

The aim of this study was to characterize the pericarp, its micromorphology and anatomical structure, in species combined in the smolkova clade (Viscaria group) and to consider the importance of these characteristics for systematics of the group. A comparative analysis also includes two species of the genus Ixoca, previously attributed to this group.

\section{MATERIAL AND METHODS}

The study is based on mature fruits (capsules) of five species (15 specimens) from Herbaria LE and KW, carpological collection (Lec) of Botanical Museum of Komarov Botanical Institute, and those collected in nature. The accepted taxonomy of the group corresponds to the classification of Tzvelev (2001). The following specimens were investigated:

Atocion armeria (L.) Raf.: Park of Komarov Botanial Institute, 4 IX 2004, N.N. Tzvelev 26 (LE); Gomelskaya Province, Dobrush station, 25 VII 1926, Ju. Krechetovich 24 (LE); St.-Petersburg, lawn in S. Kowalewskaya street, IX 2014, G.Ju. Konechnaya; Far East, Blagoveshchensk, Amur Branch of the Botanical Garden-Institute FEB RAS, IX 2016, Ya.V. Bolotova.

Ixoca arcana (Zapał.) Ikonn.: West Ukraine, Stanislavskaya (Ivanovo-Frankowskaya) oblast, 21 VII 1940, A.I. Pojarkova et al. (LE); Botanical Museum of Komarov Botanical Institute, LEc № 9833.

Ixoca carpatica (Zapał.) Ikonn.: Herb. Mus. Univ. Leopoldinensis N 104699, Carpathians, Charnohora, VIII. 1927, J. Mądalski (LE); Ivanovo-Frankowskaya oblast, 28 VI 1963, I.V. Artemchuk (LE);

Minjaevia rupestris (L.) Tzvelev. Karelia, the bank of Lake Onega, cape Cherest, 26 VII 2013, G.Ju. Konechnaya (LE); Prov of Nuland, between stations Oggelbu and Frederixberg, 15.07.1911, N.V. Shipchinsky 1138 (LE); Finland, Lojo, V. Rotert, 31VII (LE); Finland, Lojo, V. Rotert 2563 (LE);

Viscaria vulgaris Bernh. Ukraine, Velikolukskiy district, 22 VI 1921, Bulavnina et al. (KW); Pskov region., Oparino village, 14 VIII 1915, Kuznetsov, LEc № 9832; Moscow, Main Botanical Garden, A.N. Shvetsov.

The investigation was carried out using equipment of Core Centre "Cell and Molecular Technology in the Plant Science" at the Komarov Botanical Institute (St. Petersburg). The pericarp surface was studied using SEM Jeol JSM-6390LA (JEOL, Japan) in two regions: beneath the teeth and in the middle. The classification and terminology by Barthlott (1981), Murley (1951), and Botanical Latin (Stern 1973) were used for its description. The anatomical structure of the pericarp was studied using light and scanning electron microscopes along the entire length of the capsule. Longitudinal sections of the capsule walls were 
made in the middle of the carpel, cross sections - in two regions, beneath the teeth and in the capsule middle. For anatomical study, fruits were first softened with heating in a mixture of water, $96 \%$ ethanol and glycerol in equal proportions. Sections of the pericarp 12 and $24 \mu \mathrm{m}$ thick were prepared using freezing microtome. The sections were stained with phloroglucinol with sulfuric acid, gentianviolet, by toluidine blue, Sudan IV for the detection of lignin and cutin in the pericarp tissues. To determine the locality of silica in the cell walls, the fragments of capsules were kept for 48 hours in hydrofluoric acid. Observations were made, and photomicrographs were taken using light microscope AxioImager A1 (Carl Zeiss) equipped with digital imaging AxioCam MRc5 and software AxioVision (Carl Zeiss).

\section{RESULTS}

The observations show that mature capsules of the species studied are not large: for $A$. armeria and $V$. vulgaris, they are 5-10 мм in length, with long carpophore, lesser and with short carpophore in Ixoca species $(5-7 \mathrm{~mm})$ and $M$. rupestris $(3-4 \mathrm{~mm})$. They are thin-walled, cylindrical (A. armeria), cylindrical and elongated-ovate (I. arcana, I. car- patica), ovate ( $V$. vulgaris, $M$. rupestris). The peculiarity of Ixoca is longer than in other species, not limited to the teeth, the area of capsule cracking. Ixoca capsules, perhaps, represent the transition to the capsules, opening via septa; these capsules are also thin and fragile, easily destroyed.

Several transversal pericarp regions (belts) may be distinguished along the fruit: a teeth region, a region of largecelled exocarp beneath the teeth (sometimes is not developed), a middle small-celled region, a base region of thickwalled cells, somewhat lesser than above.

In the capsule teeth the pericarp is, more or less, thickened (Figs 1-4). Its sclerenchymatous part is mainly two-layered; exocarp sclereids in most genera are radially elongated, with the strongly U-shaped thickened wall. The thickenings of radial walls have the form of transversal (in relation to fruit) strands. Mesocarp sclereids are, more or less, large and longitudinally elongated, radially elongated at the ends of teeth (Fig. 3C), constitute of 1 or 1-2 layers, in the outer layer they have strongly thickened outer walls.

Beneath the teeth, the pericarp is thinner, includes two sclerenchyma layers, both at the top of a capsule and in the middle, where the number of layers reduced to one in Ixoca species (Fig. 4G, H). Structural differences between

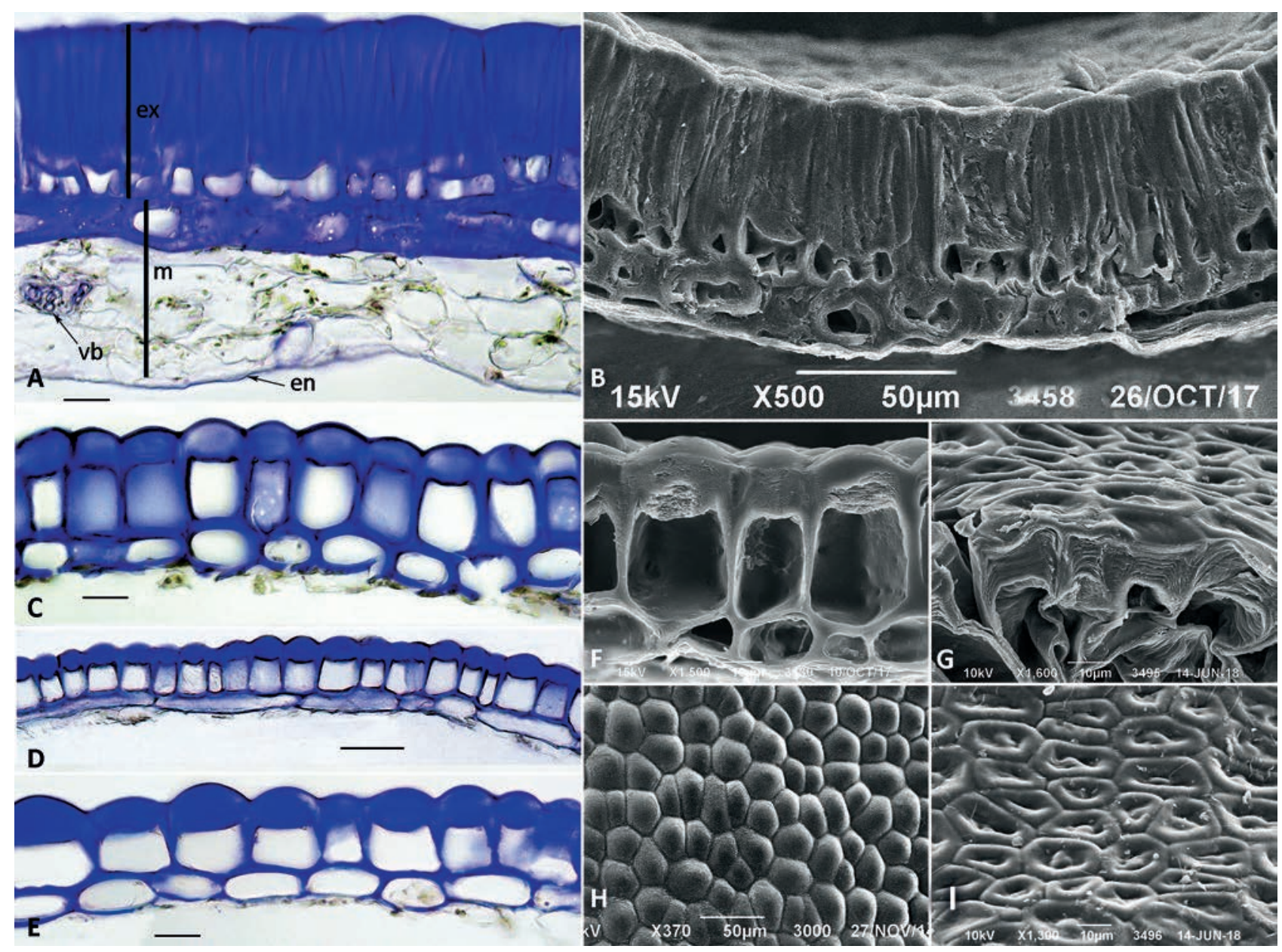

Figure 1 Pericarp structure in Atocion armeria (L.) Raf. A, B - longitudinal sections of pericarp in the teeth region; C, E - cross sections of the sclerified part of pericarp: beneath teeth (C), in capsule middle (E); D - longitudinal section of the sclerenchymatous part of the pericarp; F, G - cross section of exocarp before and after treatment with hydrofluoric acid, respectively; H, I - exocarp surface before and after treatment with hydrofluoric acid, respectively; A, C-E - LM, B, F-I - SEM. Structural elements: en - endocarp, ex - exocarp, $m$ mesocarp, vb - vascular bundle. Scale bars: A, C, E - $20 \mu \mathrm{m}, \mathrm{B}, \mathrm{D}, \mathrm{H}-50 \mu \mathrm{m}, \mathrm{F}, \mathrm{G}, \mathrm{I}-10 \mu \mathrm{m}$ 


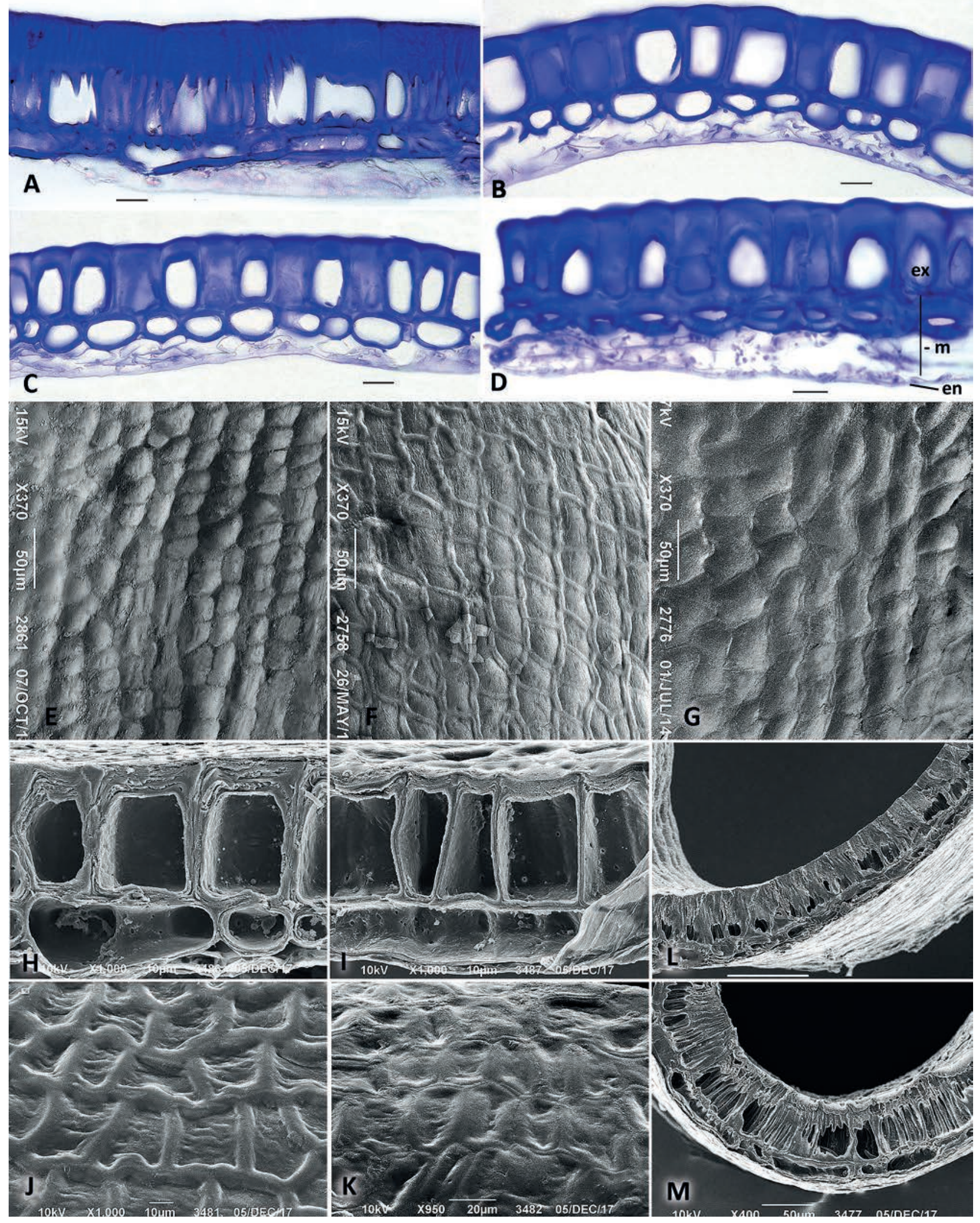

Figure 2 Pericarp structure in Minjaevia rupestris (L.) Tzvelev. A longitudinal section of the pericarp in the tooth region; B-D - cross sections of the pericarp (B - beneath the tooth, $\mathrm{C}, \mathrm{D}$ - in the capsule middle for different specimens); $\mathrm{E}-\mathrm{G}$ - the exocarp surface in different specimens; H, I - longitudinal sections of pericarp before and after treatment with hydrofluoric acid, respectively; J, K - different patches of exocarp surface after treatment with hydrofluoric acid; L, M - longitudinal sections of a capsule tooth before and after treatment with hydrofluoric acid, respectively. A-C, G, H-M - leg. Schipchinsky 1138; D - leg. Konechnaya, F - leg. Rotert. A-D - LM, E-M - SEM. Scale bars: A-D, K - $20 \mu \mathrm{m}, \mathrm{E}-\mathrm{F}, \mathrm{M}-50 \mu \mathrm{m}, \mathrm{H}, \mathrm{J}-10 \mu \mathrm{m}, \mathrm{L}-100 \mu \mathrm{m}$ 


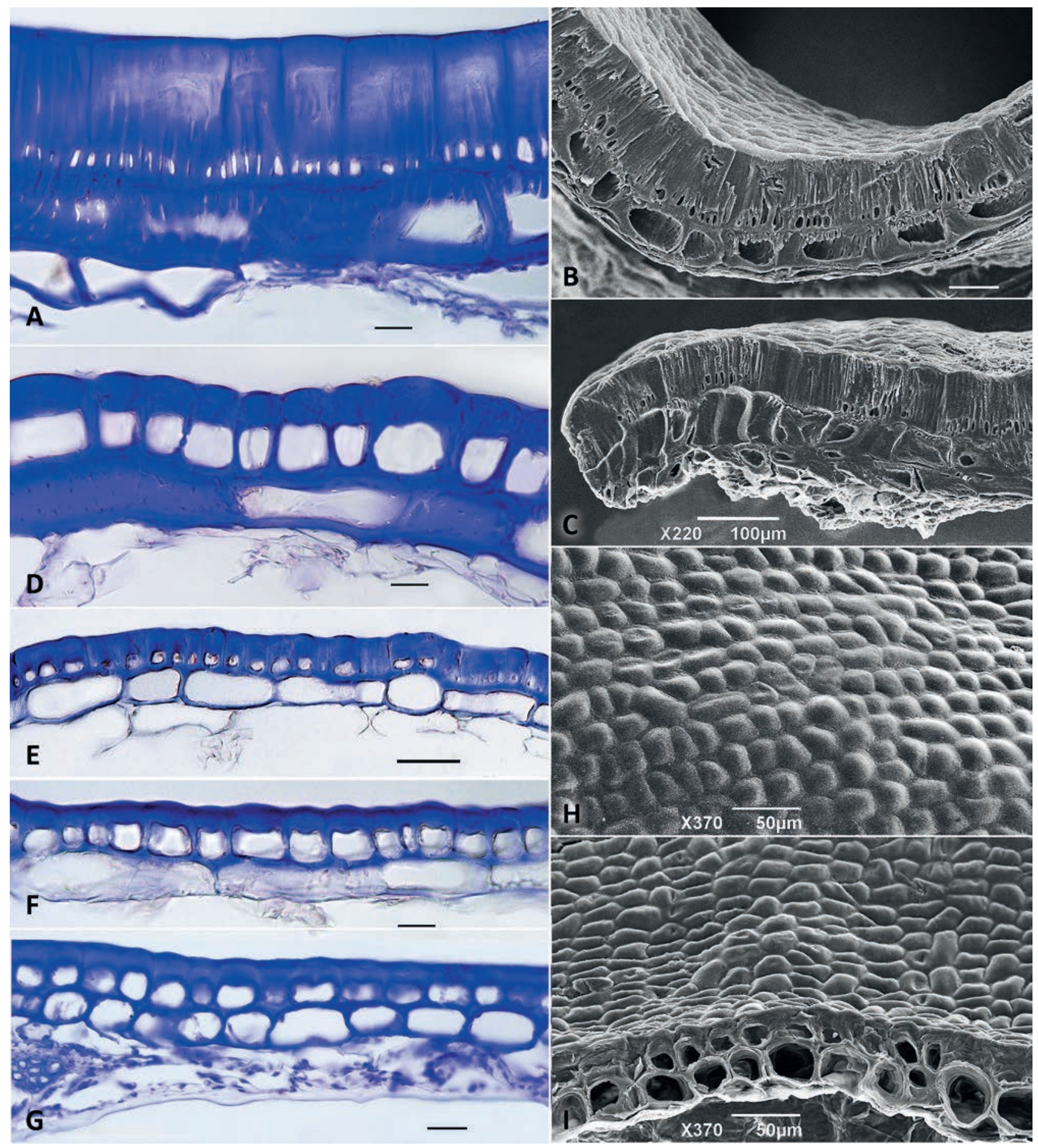

Figure 3 Pericarp structure in Viscaria vulgaris Bernh. A, B - longitudinal sections of pericarp in the tooth region. The arrow points at the inner fragmentary sclerified laver; $\mathrm{C}$ - tip of a tooth; D - longitudinal section of the pericarp sclerenchyma beneath the tooth; E-G longitudinal (E, F) and cross $(\mathrm{G})$ sections of the pericarp in the capsule middle; $\mathrm{H}$ - exocarp surface; I - cross section of the pericarp and its surface after treatment with hydrofluoric acid; A-E, I - Pskov region, leg. Kuznetsov; F-H - Velikolukskiy district, leg. Bulavnina. A, D-G - LM, B, C, H, I - SEM. Scale bars: A, D, F, G - $20 \mu \mathrm{m}, \mathrm{B}, \mathrm{E}, \mathrm{H}, \mathrm{I}-50 \mu \mathrm{m}, \mathrm{C}-100 \mu \mathrm{m}$

different parts of the fruit are usually small; they concern cell's altitude and thickness of cell walls. In the capsule middle, the sclerified zone of the mesocarp is represented by lignified parenchyma. The pericarp has a general plan of the structure and is differentiated into exo-, meso-, and endocarp (Fig. 1A, 2D). Hard exocarp, developed from the outer epidermis of the ovary, consists of sclereids having different shapes and orientation relative to the longitudinal axis of the fruit, and differently thickened wall. The mesocarp, developing from the mesophyll, includes the outer sclerified zone of elongated along the fruit, often fiber-like cells (sclereids under the teeth, parenchyma cells below) and the inner parenchymatous zone beneath. Indistinctly visible membranous, usually structureless endocarp consists of compressed cells of inner epidermis with slightly thickened outer tangential walls. Vascular bundles of middle ribs and 


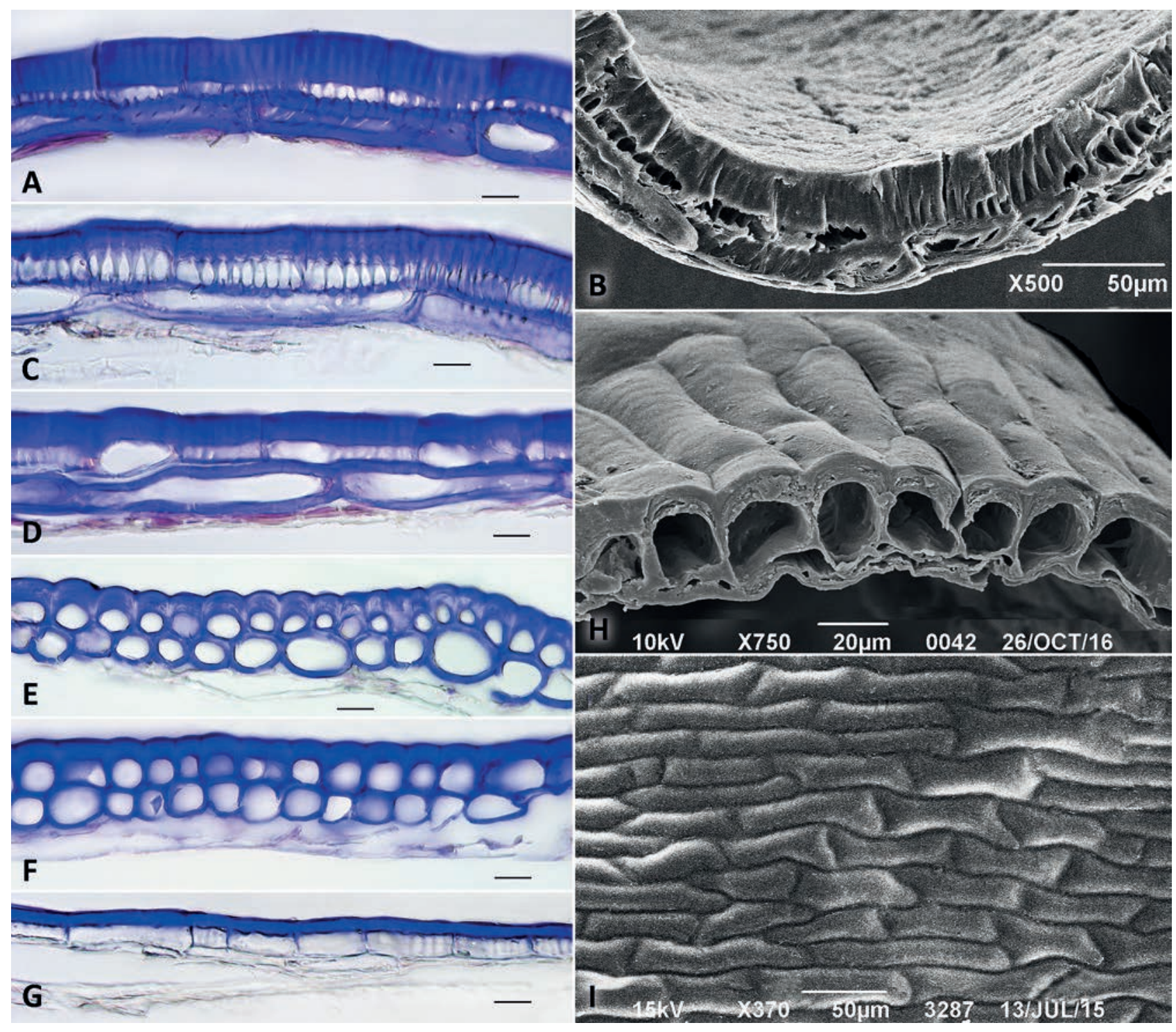

Figure 4 Pericarp structure in Ixoca arcana (Zapał.) Ikonn. and I. carpatica (Zapał.) Ikonn. A-C - longitudinal sections of the pericarp or sclerenchyma layers only in the tooth region ( $\mathrm{A}, \mathrm{C}$ - different fragments of different thickness); $\mathrm{D}$ - longitudinal section of the pericarp sclerenchyma layers beneath the tooth; E, F, H - cross sections, and $\mathrm{G}$ - longitudinal section of pericarp or sclerenchyma layers only in the capsule middle; I - exocarp surface. A, B, D, E, H - I. carpatica C, F, G, I - I. arcana. A, C-G - LM, B, H, I - SEM. Scale bars: A, C-H $-20 \mu \mathrm{m}, \mathrm{B}, \mathrm{I}-50 \mu \mathrm{m}$

their branches are situated in the parenchyma of the mesocarp, under the sclereids. Exo- and endocarp are covered with thin cuticle. In the region of middle ribs and septa between locula, exocarp sclereids are low and narrow, smaller than neighboring cells, and mesocarp sclereids in these places are usually smaller and more thick-walled, in $A$. armeria and $V$. vulgaris they are situated in two layers. In $V$. vulgaris, this special pericarp structure is characteristic only for the midrib regions, the septa region is notable only for more layers (two) of mesocarp sclereids.

Atocion armeria. In the capsule teeth, the pericarp is $80-100 \mu \mathrm{m}$ thick, with two-layered sclerenchyma (Fig. 1A, B), sometimes three-layered in some places. Exocarp sclereids are radially elongated $60-80 \mu \mathrm{m}$ thick, with a small cavity. Mesocarp sclereids are much lower, mostly compressed, somewhere rounded, wall thickenings are porous with round pits, in places are similar with those in the exocarp.
Beneath the teeth, there is a large-celled region of the exocarp about half the teeth length (Fig. 1C, F). The pericarp is $70-90 \mu \mathrm{m}$ thick, with two-layered sclerenchyma (in septa and midrib it is three-layered), with crenate outer borderline; exo- and mesocarp sclereids are smaller in comparison with teeth. In the exocarp, they are low columnar, mushroom-shaped, 50-60 $\mu \mathrm{m}$ in height, with irregularly thickened walls; their outer tangential wall is strongly thickened, lenticular to round in section. Mesocarp sclereids are smaller, oval, rarely rounded in cross-section, of different diameters. In the capsule middle the pericarp is thinner (40-70 $\mu \mathrm{m}$ thick), consisting of more thinwalled and less tall cells (Fig. 1 D, E). Exocarp sclereids are $30-50 \mu \mathrm{m}$ thick, radially elongated on the longitudinal section, infrequently cuboid on the transverse section, because the cells are often slightly elongated across the fruit (Fig. 1H). The mesocarp consists of compressed lignified parenchyma cells. 
Exocarp surface has a colliculate primary sculpture (Fig. $1 \mathrm{H})$. A treatment of the pericarp with hydrofluoric acid resulted in thinning of the sclereid walls in the exocarp, which indicates the presence of silica in them. Dissolution of silica, positioned by layers, caused the outer tangential wall caved into the cell cavity (Fig. 1G, J). Due to this, the sculpture of the exocarp surface has become annulate (Fig. 1J): the cell boundaries are still marked by a groove, the peripheral part of the outer cell wall is convex and has the form of a round roller; its central part is concave with protruding tubercle centered.

Minjaevia rupestris. In the capsule teeth, the pericarp is $75-105 \mu \mathrm{m}$ thick, with two-layered sclerenchyma (Fig. 2A, L, M). The thick-walled sclereids of the exocarp, radially elongated or cuboid, have a rather large, irregularlyrectangular cell lumen. Mesocarp sclereids are much smaller, compressed and elongated along the fruit, with round pits in the wall. Somewhere wall thickenings are similar to those that exist in the exocarp.

Beneath the teeth, there is a large-celled region in the exocarp approximately the same length as teeth. The pericarp is $60-90 \mu \mathrm{m}$ thick, with smooth outer borderline (Fig. 2B). In the capsule middle it is slightly thinner due to thinner-walled and less tall sclerenchyma cells (Fig. 2C). Exocarp sclereids are mostly radially elongated, $35-55 \mu \mathrm{m}$ in height, fenestrate in section, with a large cavity and scarcely convex outer tangential walls. The form of thickenings of their walls is different between specimens (Fig. 2B-D): in sclereids with less thickened walls the thickenings of their outer walls are poorly expressed lenticular or falcate, and the large lumen is irregularly rounded-rectangular (Fig. 2B, C). In other specimens the sclereids have thicker walls with another wall thickening and an ovate or rounded-triangular cell lumen in the cross section. Mesocarp sclereids are oval, unequal-oval, or round in the cross section.

Exocarp micromorphology, as well as its anatomy, varies between different specimens. The outer wall of exocarp cells can be slightly convex, smooth or slightly concave. Therefore, in addition to the usual colliculate primary exocarp sculpture with slightly convex outer tangential cell walls (Fig. 2E), there is a reticulate-colliculate (Fig. 2F), shallow-reticulate, smooth with reticulate pattern, as well as transitional type with weakly expressed reticulation and cells of irregular form (Fig. 2G).

After the treatment with hydrofluoric acid the cell walls in sclerenchyma layers of the pericarp become thinner (Fig. 2H, I), especially the outer tangential wall of the exocarp sclereids, which turned out to be concave into the cell cavity. The sculpture of the treated exocarp surface also varies in specimens. Basically, it is reticulate (Fig. 2J), somewhere foveate-reticulate (Fig. $2 \mathrm{~K}$ ), and cell boundaries being not marked by a groove, sometimes is similar to that in A. armeria - feebly marked annulate. After silica dissolution, teeth sclereids changed also: their cavity increased in both sclerenchyma layers, and the pits, separating in the exocarp vertical strands of the wall thickenings, became wider, making the strands more clearly visible (Fig. 2L, M).

Viscaria vulgaris. In the capsule teeth the pericarp is 100-150 $\mu \mathrm{m}$ thick, with two-three layered sclerenchyma
(Fig. 3A-C); the inner sclerified layer is weakly developed, discontinuous (shown with the arrow in Fig. 3A). It is represented by compressed lignified parenchyma cells. Exocarp sclereids are radially elongated, $60-80 \mu \mathrm{m}$ in height, with strongly thickened cell wall, and a small lumen. The sclereids of outer mesocarp layer are large, only slightly smaller in height of the exocarp sclereids, slightly longitudinally elongated, radially elongated at the tooth end (Fig. 3C). They are thick-walled; wall thickenings are porous with linear pits, in places similar to those in the exocarp.

Beneath the teeth the large-celled region of the exocarp is short. The pericarp is $70-85 \mu \mathrm{m}$ thick, with a smooth outer borderline (Fig. 3D). The sclereids are large in both layers, almost equal in height. They are radially elongated or cuboid in the exocarp, and longitudinally elongated in the underlying layer. In the capsule middle (Fig. 3E-G) the pericarp is $40-60 \mu \mathrm{m}$ thick, sclerenchyma cells of both layers are much smaller and sometimes are more thin-walled than above. Exocarp sclereids are from low columnar (Fig. 3E) to slightly tangentially elongated (Fig. 3F, G, H), with a poorly pronounced lenticular thickening of the outer tangential wall, arciform or horseshoe-shaped in section; one or the other type prevails, depending on the specimen. The mesocarp consists of large, longitudinally elongated lignified parenchyma cells, both prosenchymatous and widely oval. The primary sculpture of the exocarp is colliculate (Fig. $3 \mathrm{H}$ ). It is virtually unchanged or slightly changed after the treatment with hydrofluoric acid (Fig. 3I); most of the exocarp sclereids retain the convex outer wall.

Ixoca. The pericarp of Ixoca carpatica and I. arcana has similar structure, there are slight differences regarding cell shape from above (see later) and their altitude in teeth: higher (up to $40 \mu \mathrm{m}$ ) in I. carpatica, instead of approximately $30 \mu \mathrm{m}$ in I. arcana.

In the capsule teeth, the pericarp is 50-60 $\mu \mathrm{m}$ thick, with two-layered sclerenchyma (Fig. 4A-C). Exocarp sclereids are longitudinally to transversely elongated on the longitudinal section, $30-40 \mu \mathrm{m}$ thick, thickenings of their radial walls are weaker in comparison with other species, have the form of thin strands at the cell base. Mesocarp sclereids are large, thick-walled, longitudinally and obliquely elongated, the same height as exocarp sclereids, their radial walls are with linear pits.

Beneath the teeth (Fig. 4D) the large-celled region of the exocarp is almost absent, consists of few cells. In the capsule middle, the pericarp is $35-50 \mu \mathrm{m}$ thick, two-layered (Fig. 4E, F), or 15-30 $\mu \mathrm{m}$ thick, single-layered in less sclerified capsules; the cell structure remained only in the exocarp (Fig. 4G, H). Exocarp sclereids are small, 15-30 $\mu \mathrm{m}$ in height, does not exceed the sclereids of underlying layer in height, horseshoe-shaped, radially elongated or square in cross section, with arciform outer tangential wall, crosshatched from above (Fig. 4H); longitudinal radial walls are provided with scalariform thickenings, which change to reticulate and porous thickenings with round pits (Fig. 4D, G). Mesocarp cells are longitudinally elongated.

Exocarp surface has striate or reticulate-striate primary sculpture (Fig. 4J) in different capsule regions, in I. arcana mostly reticulate-striate. Exocarp sclereids in I. carpatica are 
60-225 $\mu \mathrm{m}$ long, linear, fiber- and bone-like (osteosclereids), with convex outer walls. In I. arcana, they are shorter (30$130 \mu \mathrm{m}$ ), oblong or elongated-polygonal to linear. After the treatment with hydrofluoric acid the outer tangential wall of the exocarp sclereids is slightly concave, convex or smooth, has wrinkled secondary sculpture; with longer exposure to the acid, the exocarp surface becomes shallow-reticulate.

\section{DISCUSSION}

The results of comparative anatomical study of fruit in the representatives of the tribe Sileneae revealed several taxonomically important pericarp characters: a number of pericarp layers in upper and low capsule parts, heights and shapes of the exocarp sclereids and the form of their wall thickenings. Earlier, Weberbauer (1898) displayed a high value of the capsule teeth structure. Our results allow supplementation of the diagnostic features with the character of the ratio of sclereid's height in exo- and mesocarp and silica absence or presence in the sclereid walls.

Changes in the thickness of the exocarp sclereids walls, which we observed in $A$. armeria, $M$. rupestris and $I$. arcana after pericarp treatment with hydrofluoric acid, indicate a significant amount of silica in them, located in layers, especially a lot in the thick outer wall, and also in the pores area in the teeth. In the treated pericarps of these species, the sculpture of the exocarp surface has changed (and in different way in $A$. armeria and $M$. rupestris) in comparison with an intact one due to silica dissolution in the outer tangential cell walls and their concavity. In $V$. vulgaris, such changes are absent or weakly expressed, which indicates a minor role of silica (if any) in the construction of the pericarp of this species.

For the species studied, three main types of the exocarp sclereids may be distinguished beneath teeth:

1) large, $30-60 \mu \mathrm{m}$ in height, forming a palisade layer, exceeding the height of mesocarp sclereids considerably, columnar or cuboid, mushroom-shaped or fenestrate in section, with a more or less convex outer tangential walls, impregnated with silica; they correspond to colliculate, reticulate or transitional form (Minjaevia) of primary sculpture of the exocarp surface in Atocion and Minjaevia;

2) small, $20-40 \mu \mathrm{m}$ in height, not forming a palisade layer, less than or equal to the height of mesocarp sclereids, for the most part low columnar or cuboid, horseshoe or arcuate in section, with poorly convex outer tangential wall, not impregnated with silica (?or weakly impregnated); they correspond to the colliculate sculpture of the exocarp surface in Viscaria;

3) low, 15-30 $\mu \mathrm{m}$ in height, longitudinally elongated, from above polygonal to linear, fiber- or bone-like, horseshoe in section, less than or equal to the height of mesocarp sclereids, correspond to the striate or reticulate-striate sculpture in Ixoca.

Depending on the form of the cell wall's thickenings, two variants of sclereids can be distinguished within the type (1): mushroom-shaped sclereids in $A$. armeria with convex outer wall, lenticular to round in section; the sclereids with poorly convex outer tangential wall in $M$. rupestris, fenestrate in section, either with irregularly roundedrectangular cell lumen and slight lenticular thickening of the outer cell wall or with ovate cell lumen and the outer cell wall mainly without the lenticular thickening.

The mesocarp sclereids are either mostly prosenchymatous, longitudinally elongated (Atocion, Minjaevia, Ixoca), or broader, sometimes broadly oval, the same height as in the exocarp (Viscaria).

The results obtained confirm the lack of close relationships between Ixoca and the genera of the Viscaria group. The genus is peculiar in the striate and reticulate-striate primary sculpture of the exocarp surface, and the structure of exocarp sclereids - longitudinally elongated, often osteosclereids and fiber-like sclereids having secondary thickenings of longitudinal radial walls. It differs from other species by a similar form of the sclereids in the both sclerenchyma layers and having the same orientation in relation to the fruit. The capsule teeth also have a special structure: though the sclerenchyma is two-layered (a common feature for other genera of the Viscaria group), the exocarp sclereids are tangentially (not radially) elongated, provided with weaker wall thickenings. Such teeth structure, as Weberbauer (1898) noted, is also available in Petrocoptis and members of certain genera (Arenaria, Moebringia) of the tribe Alsineae. Petrocoptis is also indicated as one of the possible ancestors of the genus Ixoca based on molecular studies (Fraiman, Eggens \& Oxelman 2009).

The analysis of the pericarp structure in the Viscaria group showed that despite the differences in the capsule morphology and pattern of its opening in $A$. armeria and $M$. rupestris on the one hand, and $V$. vulgaris on the other, there are many similar features in their pericarp anatomy and micromorphology that supports a close relationship of these taxa. The primary sculpture of exocarp surface is colliculate, the pericarp is thin, the sclerenchyma is two layered both on top of the capsule and in the middle. Structural differences between different parts of the fruit are small and relate mainly to cell height and thickness of cell walls. In the middle of the fruit the mesocarp is represented by lignified parenchyma. The exocarp sclereids are low columnar or cuboid, with convex (in different degrees in the species) outer tangential wall. The capsule teeth are formed mainly by two sclereid layers as well, what distinguishes this group from most of Sileneae, having multicellular teeth, composed of three layers of sclereids.

The greatest similarity in the pericarp structure, as in the capsule morphology, is between Atocion armeria and Minjaevia rupestris: both have a large-celled region in the exocarp beneath the teeth; moreover, the exocarp sclereids exceed considerably the mesocarp sclereids in height and have a large cavity. The mushroom-shaped exocarp sclereids turned out to be a distinctive character of Atocion armeria. Silica locality in the outer tangential cell walls is different between the two species as follows from different sculpture of treated exocarp surface.

Several structural and chemical differences of the pericarp mark out Viscaria vulgaris in the group studied. The lack of palisade layer, not impregnated with silica cell walls of the pericarp sclereids, and less pronounced differentiation of pericarp sclerenchyma into two different (morphologically and in cell orientation) cell layers 
determine less derived pericarp structure in Viscaria in comparison with Atocion and Minjaevia. The distinctive features also include a big contrast between the large-cellular pericarp in teeth and small-cellular one in the rest part of a capsule, the absence of the large-celled region in the exocarp beneath the teeth. The presence of the third, discontinuous inner lignified layer in the teeth can be a sign of their transitional structure to Silene.

It should be noted that for Minjaevia rupestris, unlike other species studied, a prominent infraspecific variation of both exocarp micromorphology and anatomical structure is characteristic. The exocarp surface sculpture may be a colliculate, reticulate-colliculate, reticulate or intermediate type; the exocarp sclereids differ in the form of wall thickenings between specimens.

\section{ACKNOWLEDGEMENTS}

The authors appreciate the help of the curators of Herbaria LE and KW, the carpological collection of Komarov Botanical Institute (Lec) from which material was received; G.Ju. Konechnaya, N.A. Trusov and V.N. Shvetsov are appreciated as well. We are grateful to L.A. Kartseva, the head of scanning electron microscopy branch of the Core Facility Center "Cell and Molecular Technologies in Plant Science" in LE for technical assistance in SEM studies. The project was supported by the Russian Foundation for Basic Research (grant № 16-34-50028 mol_nr).

\section{LITERATURE CITED}

Barthlott, W. 1981. Epidermal and seed surface characters of plants: systematic applicability and some evolutionary aspects. Nordic Journal of Botany 1(3):345-355.

Chowdhuri, P.K. 1957. Studies in the genus Silene. Notes from the Royal Botanic Garden Edinburg 22(3):221-278.

Devyatov, A.G. 1991. On the types of capsule opening in the tribe Lychnideae Fenzl. in Endlicher (Caryophyllaceae). Byulleten' Moskovskogo obshchestva ispytatelei prirody. Otdel biologicheskii 5: 64-69 (in Russian with English summary). [Aeвятов А.Г. О типах вскрывания коробочек в трибе Lychnideae Fenzl in Endlicher (Caryophyllaceae) // Бюм^етень Московского общества испытателей природы. ОтАел биологический. Вып. 5. С. 64-69].

Erixon, P. \& B. Oxelman 2008. Reticulate or tree-like chloroplast DNA evolution in Sileneae (Caryophyllaceae)? Molecular Phylogenetics and Evolution 48:313-325.

Frajman, B. \& B. Oxelman 2007. Reticulate phylogenetics and phytogeographical structure of Heliosperma (Sileneae, Caryophyllaceae) inferred from chloroplast and nuclear DNA sequences. Molecular Phylogenetics and Evolution 43(1): 140-155.

Frajman, B., N. Heidary \& B. Oxelman 2009. Phylogenetic relationships of Atocion and Viscaria (Sileneae, Caryophyllaceae) inferred from chloroplast, nuclear ribosomal, and low-copy gene DNA sequences. Taxon 58(3):811-824.

Frajman, B., F. Eggens \& B. Oxelman 2009. Hybrid origin and homoploid reticulate evolution within Heliosperma (Sileneae, Caryophyllaceae) - a multigene phylogenetic approach with relative dating. Systematic Biology 58(3):328-345.

Frajman, B., M. Thollesson \& B. Oxelman 2013. Taxonomic revision of Atocion and Viscaria (Sileneae, Caryophyllaceae). Botanical Journal of Linnean Society 173(2):194-210.
Guttenberg, H. von. 1971. Bewergungsgewebe und Perzeptionsorgane. Handbuch der Pflanzenanatomie. Berlin-Stuttgart: G. Borntraeger, 2 Aufl, V(5), 332 S.

Greuter, W. 1995. Silene (Caryophyllaceae) in Greece: a subgeneric and sectional classification. Taxon 44(4):543-581.

Kravtsova, T.I. \& V.O. Romanova 2015. Ultrasculpture of pericarp surface in species of the tribe Sileneae (Caryophyllaceae) in relation to its systematics. Botanicheskir Zhurnal 100(3):209-225 (in Russian with English summary). [Кравцова Т.И., Романова В.О. 2015. У ььтраскульптура поверхности перикарпия у видов трибы Sileneae (Caryophyllaceae) в связи с ее систематикой // Ботанический журнал. Т. 100, № 3. С. 209-225].

Kravtsova, T.I. 2017. Ultrasculpture of exocarp surface in some species of the tribe Sileneae (Caryophyllaceae). Botanicheskii Zhurnal 102(12):1608-1621 (in Russian with English summary). [Кравцова Т.И. 2017. У Аьтраскульптура поверхности экзокарпия некоторых видов трибы Sileneae (Caryophyllaceae) // Ботанический журнац. T. 102, № 12. C. 1608-1621].

Lazkov, G.A. 2003. Silene L. (Caryophyllaceae) in the flora of Eurasia: systematics, distribution, history. Sci. D. Thesis. St. Petersburg. 38 pp. (in Russian). [Аазьков Г.А. РоА Silene L. (Caryophyllaceae) во флоре Евразии: систематика, распространение, история. Аисс. Аокт. биол. наук. Санкт-Петербург. 38 с.].

Lazkov, G.A. 2006. The family cloves (Caryophyllaceae) in the flora of Kyrgyzstan. Moscow: KMK, 271 pp. (in Russian). [Аазьков Г.А. 2006. Семейство ГвозАичные (Caryophyllaceae) во флоре Кыргыстана. Москва: Товарищество научных изАаний КМК, 271 с.].

Melikyan, A.P. \& A.G. Devyatov 2000. Exocarp surface structure as a taxonomically significant feature in Caryophyllaceae. Byulleten' Moskovskogo obshchestva ispytatelei prirody. Otdel biologicheskii 105(1):54-58 (in Russian). [Меликян А.П., Аевятов А.Г. 2000. Особенности строения поверхности экзокарпия преАставителей семейства Caryophyllaceae как систематический признак / / Бюлметень Московского общества испытателей природы. ОтАел биологический. Т. 105, вып. 1. С. 54-58].

Mikhailova, Yu.V. 2016a. Taxonomic position and phylogeography of the arctic-alpine species Silene acaulis (L.) Jacq. (Caryophyllaceae). Ph. D. Thesis. St. Petersburg. 26 pp. (in Russian). [Михайлова Ю.В. 2016а. Таксономическое положение и филогеография аркто-альпийского вида Silene acaulis (L.) Jacq. (Caryophyllaceae). Аисс. канд. биол. наук. Санкт-Петербург. 26 с.].

Mikhailova, Yu.V. 2016b. DNA study for Sileneae DC. (Caryophyllaceae Juss.) systematics. In: Problems of botany in South Siberia and Mongolia: collected scientific articles on the materials of the XV international scientific-practical conference (23-25 of May 2016, Barnaul) (A.I. Shmakov \& T.M. Kopytina, eds), pp. 153-156. Concept, Barnaul (in Russian). [Михайлова Ю.В. 2016. Исследование $\Delta \mathrm{HK}$ Аля решения вопросов систематики Sileneae DC. (Caryophyllaceae Juss.) // Проблемы ботаники Южной Сибири и Монголии: сборник научных статей по материалам XV международной научно-практической конференции (23-26 мая 2016 г., Барнаул) / отв. реА. Шмаков А.И., Копытина Т.М. Барнаул: Концепт. С. 153-156].

Mikhailova, Yu.V., E E. Krapivskaia \& A.V. Rodionov 2014. Molecular phylogenetic study of the genus independence Xamilenis Raf. as part of the tribe Sileneae. Ekologicheskaya genetike 12(4):15-24 (in Russian with English summary). [Михайлова Ю.В., Крапивская Е.Е., Родионов А.В. 
2014. Молекулярно-филогенетическое исследование самостоятельности рода Xamelinis в составе трибы Sileneae // Экологическая генетика. Т. 12, № 4. С. 15-24].

Murley, M.R. 1951. Seeds of the Cruciferae of Northeastern North America. The American Midland Naturalist 46(1):1-81.

Oxelman, B. \& M. Lidén 1995. Generic boundaries in the tribe Sileneae as inferred from nuclear rDNA sequences. Taxon 44(4):525-542.

Oxelman, B., M. Lidén \& D. Berglund 1997. Chloroplast rps16 intron phylogeny of the tribe Sileneae (Caryophyllaceae). Plant Systematics and Evolution 206(1-4): 393-410.

Oxelman, B., M. Lidén, R.K. Rabeler \& M. Popp 2001. A revised generic classification of the tribe Sileneae (Caryophyllaceae). Nordic Journal of Botany 20(6):743-748.

Schishkin, B.K. 1936. Caryophyllaceae, Lychnideae. In: Flora of the USSR, vol. 6 (V.L. Komarov, ed.), pp. 573-730, Acad.
Sci. USSR, Moscow, Leningrad (in Russian). Шишкин Б.К. 1936. Caryophyllaceae, Lychnideae. // ФАора СССР / под реА. В.А. Комарова. Москва; АенинграА: Издательство АН СССР. Т. 6. С. 573-730].

Stern, W.T. 1973. Botanical Latin. Ed. 2. David and Charles, Newton Abbot, 566 pp.

Tzvelev, N.N. 2001. On genera of the tribe Sileneae (Caryophyllaceae) in Eastern Europe. Novosti Sistematiki Vysshikh. Rastenii 33:90-113 (in Russian). ЩЦвелев Н.H. О родах трибы смолевковых (Sileneae DC., Caryophyllaceae) в Восточной Европе // Новости систематики высших растений. Т. 33. С. 90-113].

Weberbauer, A. 1898. Beiträge zur Anatomie der Kapselfrüchte. Botanisches Centralbatt 73: 54-59, 97-105, 135142, 161-168, 193-202, 250-257, 296-302. 